\title{
Manajemen Mutu Pendidikan dalam Upaya Meningkatkan Kemandirian Madrasah
}

\author{
Tahrir Rosadi
}

IAINU Kebumen

\section{tahrirrosadi@gmail.com}

\begin{abstract}
This research was compiled based on the importance of implementing educational quality management in a madrasah. The focus of this research is on the implementation of quality management of eight national education standards. In this regard, research was conducted with the aim of knowing the planning, implementation, evaluation, and follow-up of educational quality management in an effort to increase the independence of madrasah in Indonesia. This study uses qualitative research. Collecting data using observation, interviews, and documentation. The validity of the data using data triangulation. Data analysis techniques include data reduction, data presentation, and drawing conclusions. This study shows that: (1) Planning for education quality management has been carried out properly. Planning begins with a joint meeting to determine the objectives to be achieved through the realization of the program. (2) The implementation of quality management in education has been carried out well. In implementation, the madrasa head is able to move educators to carry out the program according to plan. (3) Evaluation of education quality management has been carried out properly. The head of the madrasa guarantees the implementation of education quality management through supervision and implementation evaluation meetings to look for deficiencies. (4) The follow-up of education quality management has been carried out properly. The madrasa principal uses the basic evaluation stages to determine the followup steps to be taken.
\end{abstract}

Keywords: Management, Quality, Education

\begin{abstract}
Abstrak
Penelitian ini disusun berdasarkan pentingnya pelaksanaan manajemen mutu pendidikan dalam suatu madrasah. Fokus penelitian ini pada pelaksanaan manajemen mutu delapan standar nasional pendidikan. Sehubungan hal tersebut, penelitian dilakukan dengan tujuan mengetahui perencanaan, pelaksanaan, evaluasi, dan tindak lanjut manajemen mutu pendidikan dalam upaya meningkatkan kemandirian madrasah di. Penelitian ini menggunakan penelitian kualitatif. Pengumpulan data menggunakan observasi,
\end{abstract}


wawancara, dan dokumentasi. Keabsahan data menggunakan triangulasi data. Teknik analisis data meliputi reduksi data, penyajian data, dan penarikan kesimpulan. Penelitian ini menunjukkan bahwa: (1) Perencanaan manajemen mutu pendidikan sudah dilakukan dengan baik. Perencanaan diawali dengan rapat bersama untuk menentukan tujuan yang akan dicapai melalui realisasi program. (2) Pelaksanaan manajemen mutu pendidikan di sudah dilakukan dengan baik. Dalam pelaksanaan, kepala madrasah mampu menggerakan pendidik untuk menjalankan pogram sesuai rencana. (3) Evaluasi manajemen mutu pendidikan sudah dilakukan dengan baik. Kepala madrasah menjamin terlaksananya manajemen mutu pendidikan melalui supervisi dan rapat evaluasi pelaksanaan untuk mencari kekurangannya. (4) Tindak lanjut manajemen mutu pendidikan sudah dilakukan dengan baik. Kepala madrasah menggunakan dasar tahapan evaluasi untuk menentukan langkah tindak lanjut yang akan dilakukan.

Kata kunci : Manajemen, Mutu, Pendidikan

\section{PENDAHULAN}

Mutu dalam bidang pendidikan meliputi mutu input, proses, output dan outcame. Input pendidikan dinyatakan bermutu apabila siap berporses sseuai dengan standar minimal nasional dalam bidang pendidikan. Proses pendidikan dapat dinyatakan bermutu apabila mampu menciptakan suasana pembelajaran yang aktif, kreatif, inovatif dan menyenangkan sehingga tujuan pendidikan dapat tercapai dengan baik. Output dinyatakan bermutu apabila hasil belajar yang dicapai peserta didik baik dalam bidang akademik maupun non akademik tinggi. Outcame dinyatakan bermutu apabila lulusan cepat terserap dalam dunia kerja maupun lembaga-lembaga yang membutuhkan lulusan tersebut dan stakeholder merasa puas terhadap lulusan dari lembaga pendidikan tersebut. $^{1}$

Terdapat dua faktor yang menjadikan upaya peningkatan mutu pendidikan selama ini kurang maksimal antara lain: (1) Strategi pembangunan pendidikan selama ini lebih bersifat pada input oriented. Maksudnya adalah pendidikan selama ini berjalan berdasarkan pandangan bahwa ketersediaan buku pembelajaran, alat-alat pembelajaran, penyediaan sarana pendidikan, dan pengadaan pelatihan pendidik maka akan secara otomatis lembaga pendidikan yang bersangkutan akan mampu mencetak output yang bermutu sesuai dengan harapan. Peningkatan mutu yang seperti ini sebenarnya hanya ada dalam dunia bisnis saja dimana apabila input bagus maka output yang dihasilkan juga akan bagus, padahal sama sekali berbeda apabila diterapkan di dalam dunia pendidikan.

(2) Pendidikan selama ini lebih bersifat macro-oriented. Maksudnya adalah pendidikan

\footnotetext{
${ }^{1}$ Depdiknas, Manajemen Peningkatan Mutu Berbasis Sekolah (Jakarta: Direktorat Sekolah Lanjutan Tingkat Pertama, 2007).
} 
selama ini diatur oleh jajaran birokrasi tingkat pusat sehingga banyak kebijakan yang diterapkan oleh pusat tidak dapat dilaksanakan oleh lembaga pendidikan sebab tingkat kompleksitas yang berbeda antara lembaga pendidikan yang satu dengan yang lain. Hal ini menjadikan usaha peningkatan mutu pendidikan kurang maksimal. ${ }^{2}$

Melihat pentingnya peningkatam mutu yang harus dilakukan oleh lembaga pendidikan agar dapat bertahan dalam persaingan global saat ini, maka perlu adanya tindakan nyata dalam peningkatan mutu lembaga pendidikan sebagai upaya kemandirian dari lembaga pendidikan tersebut. Upaya-upaya tersebut nantinya akan berimbas pada input, output dan outcame yang dihasilkan sehingga kepercayaan masyarakat dapat bertahan dan bahkan meningkat. Salah satu bagian yang menjadi daya tarik masyarakat terhadap suatu madrasah adalah bagaimana pelaksanaan manajemen mutu yang dilakukan oleh kepala madrasah terhadap madrasah yang dipimpinnya dalam upaya meningkatkan kemandirian madarsah. Semua kebijakan pelaksanaan pembelajaran dan pengelolaan madrasah menjadi sorotan masyarakat. Sehingga perlu adanya manajemen mutu yang baik dan sistematis yang harus dilakukan oleh kepala madrasah melalui implementasi manajemen mutu pendidikan dalam peningkatan kemandirian madarsah sehingga citra madrasah di masyarakat semakin meningkat.

\section{METODOLOGI PENELITIAN}

Penelitian ini menggunakan model penelitian kualitatif. Dimana dari pegambilan data melalui wawancara, observasi, dokumentasi. Kemudian disajikan dalam bentuk deskriptif naratif.

\section{HASIL DAN PEMBAHASAN}

\section{Konsep Manajemen}

Manajemen bisa berarti fungsi, peranan, maupun keterampilan. Manajemen sebagai fungsi meliputi usaha perencanaan, pengorganisasian, pengarahan, pengkoordinasian dan pengawasan. ${ }^{3}$ Manajemen adalah serangkaian beberapa prosesyang dilakukan dalam rangka pencapaian tujuan suatu organisasi yang telah ditentukan sebelumnya dengan bantuan dari orang lain. ${ }^{4}$ Manajemen adalah proses kegiatan inti yang meliputi perencanaan, pengorganisasian, penelaksanaan dan pengawasan sebagai langkah pemberdayaan seluruh sumber daya dan potensi

\footnotetext{
${ }^{2}$ Rohiat, Manajemen Sekolah Teori Dasar Dan Praktik (Bandung: PT Refika Aditama, 2010).

${ }^{3}$ Depdiknas, Manajemen Peningkatan Mutu Berbasis Sekolah.

${ }^{4}$ S Fatimah, Perkembangan Anak Pada Masa Golden Age: Didukung Peneilitian Ilmiah Dan Panduan Islam (Surakarta: UNS Press, 2019).
} 
manajemen baik manusia, metode, material, sarana dan prasarana maupun keuangan agar dapat mencapai tujuan organisasi yang telah ditetapkan sebelumnya.

Manajemen adalah sebuah ilmu dan seni yang dilakukan dalam mengatur proses pemanfaatan sumber daya manusia dan sumber-sumber daya lainnya secara efektif dan efisien untuk mencapai suatu tujuan tertentu yang telah ditetapkan. Manajemen merupakan proses perencanaan, pengorganisasian kepemimpinan, dan pengendalian upaya anggota organisasi dan proses pembangunan sumber daya yang lain untuk mencapai tujuan secara efektif dan efisien. Pengertian lain dari manajemen adalah suatu proses sosial yang berkaitan dengan seluruh usaha yang dilakukan manusia dengan bantuan manusia lain dan dengan pemanfaatan sumber-sumber lainnya, menggunakan metode yang efisien dan efektif untuk mencapai tujuan yang sebelumnya telah ditentukan. ${ }^{5}$

Sumber lain menyatakan bahwa pengertian manajemen adalah sebuah proses yang diawali dari perencanaan, pengorganisasian, pengarahan, pemantauan dan penilaian untuk mencapai tujuan pendidikan. Pada dasarnya menejemen mutu pendidikan dapat didefinisikan sebagai suatu cara meningkatkan performance secara terus menerus pada setiap level operasiatau proses, dalam setiap area fungsional dari suatu pendidikan, dengan menggunakan semua sumber daya yang ada. Manajemen dalam pelaksanaannya memiliki tiga komponen yang tidak dapat dipisahkan antara satu dengan yang lainnya dimana komponen tersebut saling berkaitan. Ketiga komponen tersebut yaitu man atau manusia, money atau uang, dan material atau bahan atau sarana prasarana.

Berdasarkan beberapa pendapat para ahli di atas, penulis menyimpulkanbahwa pengertian manajemen adalah proses kegiatan yang meliputi perencanaan, pelaksanaan, pengawasan, dan tindak lanjut manajemen yang dilakukan dengan bantuan sumber daya manusia dan memanfaatkan sumber daya lainnya secara efektif dan efisien untuk mencapai tujuan yang telah ditentukan. Hal ini sesuai dengan teori dari W. Edwards Deming yang menyatakan bahwa langkah-langkah manajemen meliputi perencanaan (planning), pelaksanaan (do), pengawasan (check), tindak lanjut (act).

\section{Fungsi- Fungsi Manajemen}

\footnotetext{
5 Triyanto \& Rudiyati, "Pengembangan Modul Pembelajaran Aksara Jawa 'Dinta Swara' Dalam Huruf Braille Untuk Siswa Tunanetra,” Jurnal Pembanguna Pendidikan: Fondasi Dan Aplikasi 5, no. No 2 (2017): 176-86.
} 
Manajemen dalam upaya mencapai tujuan melalui serangkaian kegiatan tentunya harus memperhatikan fungsi-fungsi dari manajemen itu sendiri. Fungsifungsi manajemen menurut W. Edwards Deming meliputi perencanaan (planning), pelaksanaan (do), evaluasi (check), tindak lanjut (act). Di bawah ini penulis uraikan fungsi-fungsi manajemen menurut W. Edwards Deming adalah sebagai berikut:

a. Fungsi perencanaan

Perencanaan adalah proses kegiatan yang menyiapkan secara sistematis kegiatan-kegiatan atau tindakan yang akan dilakukan untuk mencapai tujuan serta menentukan siapa yang akan melaksanakan tugas tersebut. Adanya perencanaan berkaitan dengan perencanaan mutu, meliputi penetapan kebijakan mutu, penetapan tujuan mutu beserta indikator pencapaiannya, serta penetapan prosedur untuk pencapaian tujuan mutu Fendy Tjiptono dan Anastasia Diana. Perencanaan merupakan sebuah ativitas pengambilan keputusan tentang sasaran yang akan dicapai, tindakan yang akan diambil dalam rangka mencapai tujuan yang telah ditetapkan dan siapa yang akan melaksanakan tugas tersebut. Perencanaan yang baik akan memenuhi persyaratan perencanaan yang nantinya digunakan dalam rangka merealisasikan perencanaan sehingga dapat memberikan manfaat bagi pengguna perencanaan itu sendiri dalam hal ini lembaga pendidikan. ${ }^{6}$

Perencanaan adalah upaya persiapan dan pengalokasian berbagai usaha di masa mendatang dengan maksud dan tujuan mempengaruhi dan mengendalikan arah perubahan yang dikehendaki dengan kata lain perencanaan merupakan sebuah aktifitas memutuskan sesuatu yang akan dilaksanakan dimasa yang akan datang (Lijan Poltak Sinambela, 2016:57). Oleh karena itu, perencanaan dianggap sangat penting sebagai gambaran awal kegiatan. Sejalan dengan pernyataan tersebut, untuk membuat perencanaan yang baik sebelum melakukan suatu perbuatan atau tindakan secara tersirat telah disebutkan di dalam Al-Qur'an pada Surat Al-Hasyr (59) ayat 18 sebagai berikut:

Artinya: "Hai orang-orang yang beriman, bertakwalah kepada Allah dan hendaklah Setiap diri memperhatikan apa yang telah diperbuatnya untuk hari esok (akhirat); dan bertakwalah kepada Allah, Sesungguhnya Allah Maha mengetahui apa yang kamu kerjakan".

\footnotetext{
${ }^{6}$ A. D Mahmudah, U., Suhartono, S., \& Rohayana, "A Robust Data Envelopment Analysis for Evaluating Technical Efficiency of Indonesian High Schools," . Jurnal Pendidikan IPA Indonesia VOL 7, no. 1 (2018): $114-121$.
} 
Ayat tersebut menjelaskan tentang perintah kepada orang-orang yang beriman untuk bertaqwa kepada Allah SWT dan memperhatikan (mempersiapkan dengan baik) apa yang akan diperbuatnya untuk hari esok. Dalam ilmu manajemen tindakan ini disebut perencanaan (planning). Untuk meningkatkan mutu pendidikan maka pimpinan madrasah bersama seluruh stakeholders perlu merumuskan perencanaan pengembangan dan target pencapaian prestasi madrasah dalam bentuk rencana strategis madrasah.

Fungsi perencanaan meliputi penetapan tujuan organisasi, penentuan strategi kegiatan yang meliputi kebijakan sistem dan penetapan anggaran, serta pembuatan keputusan kegiatan perencanaan yang akan dilakukan. Melalui perencanaan diharuskan adanya usaha pemersatuan sumber-sumber daya yang efektif dalam rangka usaha mencapai sasaran-sasaran yang telah ditetapkan sebelumnya. Dengan demikian perencanaan juga memberikan batasan-batasan tindakan yang akan dilakukan sehingga hambatan yang akan dihadapi dapat dikurangi.

Perencanaan disebut juga sebagai sebuah upaya yang dilakukan oleh manusia untuk mengambil langkah-langkah kebijakan yang harus dioperasionalkan. Dengan demikian perencanaan sangat penting dilakukan sebagai gambaran awal tindakan yang harus dilakukan dalam proses pencapaian tujuan. Dalam membuat perencanaan hendaknya mengetahui sifat-sifat perencanaan yaitu bahwa perencanaan harus mampu menyumbang pada pencapaian tujuan-tujuan organisasi. Perencanaan merupakan dasar tolak ukur fungsi manajemen yang lain meliputi pengarahan, koordinasi dan pengawasan.. Perencaanaan juga harus bersifat efisien yaitu tujuan dapat tercapai dengan biaya sekecil-kecilnya .

Perencanaan pada pendidikan tidak hanya diarahkan pada kesempatan pencapaian kesempurnaan dan kebahagiaan dunia saja, akan tetapi perencanaan juga harus diarahkan pada kesempurnaan ukhrawi secara berimbang. Sanusi Uwes, dalam bukunya menerangkan bahwa tindakan perencanaan manajemen pendidikan meliputi berbagai aspek, diantaranya adalah:

1) Melakukan penelitian prioritas agar pelaksanaan pendidikan berjalan secara efektif, sesuai dengan prioritas kebutuhan agar melibatkan semua komponen secara langsung dalam proses pendidikan.

2) Menetapkan tujuan sebagai garis pengarahan dan juga sebagai evaluasi terhadap pelaksanaan dan hasil dari pendidikan. 
3) Membuat rancangan prosedur sebagai bagian dari tahapan rencana tindakan.

4) Membagi tanggung jawab baik kepada individu maupun kelompok.

Tahap-tahap yang perlu dilakukan dalam melakukan perencanaan yaitu melakukan identifikasi masalah, melakukan perumusan masalah, menetapkan tujuan, mengidentifikasi alternatif, kemudian melakukan pemilihan alternatif dan mengelaborasi alternatif. Hasil yang diperoleh dari adanya penyusunan perencanaan adalah munculnya sebuah gagasan-gagasan yang mencakup tindakantindakan yang akan dilakukan yang sudah ditentukan sebelumnya.

Perencanaan dianggap sangat penting sebab jika melakukan pekerjaan tanpa ada rencana tentunya pekerjaan tersebut tidak dapat diselesaikan. Maka dari itu, ada beberapa manfaat yang dapat diambil dari apabila seorang manajer melakukan sebuah perencanaan adalah sebagai berikut:

1) Menghasilkan sebuah rencana yang dapat dijadikan sebagai keragka kerja dan pedoman penyelesaian pekerjaan.

2) Rencana menentukan proses yang paling efektif dan efisien untuk mencapai tujuan.

3) Dengan adanya rencana, setiap langkah dapat diukur atau dibandingkan dengan hasil yang seharusnya dicapai.

4) Perencanaan mencegah pemborongan uang, tenaga dan waktu.

5) Perencanaan mempersempit timbulnya gangguan dan hambatan (Suharsimi Arikunto.dkk, 2009:9).

Kegiatan perencanaan dilakukan melalui beberapa tahapan yang harus dilakukan agar perencanaan dapat meghasilkan keputusan yang tepat. Hani Handoko menyatakan bahwa tahapan-tahapan perencanaan tersebut adalah sebagai berikut:

1) Menetapkan tujuan dilakukan dengan menghimpun beberapa keputusankeputusan kebutuhan organisasi yang menjadi prioritas.

2) Merumuskan keadaan saat ini dilakukan dengan membuat gambaran rencana kegiatansebagai acuan dasar kegiatan yang akan datang.

3) Mengidentifikasikan segala kemudahan dan hambatan dilakukan dengan menghimpun beberapa faktor-faktor yang meliputi analisi keadaan, masalah dan kesempatan, serta ancaman yang mungkin terjadi pada katu yang akan datang. 
4) Mengembangkan rencana atau serangkaian kegiatan untuk pencapaian tujuan dilakukan dengan mengembangkan berbagai alternatif kegiatan untuk pencapaian tujuan dengan cara pemilihin dari beberapa alternatif yang ada.

Berdasarkan keterangan di atas dapat disimpulkan bahwa fungsi dari adanya perencanaan adalah sebuah proses pengambilan keputusan yang sistematis melalui berbagai tahapan-tahapan mengenai gagasan - gagasan yang telah disepakai bersama sebagai acuan dan batasan terhadap tindakan yang akan dilakukan. Dengan adanya perencanaan yang matang diharapkan akan menjadi langkah awal yang baik untuk tercapainya sebuah tujuan.

b. Fungsi Pelaksanaan

Pelaksanaan adalah upaya untuk menggerakkan atau mengarahkan tenaga kerja serta melakukan pendayagunaan fasilitas yang tersedia dengan maksud untuk melakukan pekerjaan secara bersama-sama secara sistematis. Adanya pelaksanaan dari apa yang sudah direncanakan. Maka untuk menjamin mutu pendidikan, seluruh proses pendidikan, termasuk pelayanan administrasi pendidikan dilaksanakan sesuai dengan SOP yang telah ditentukan.

Upaya menggerakan dan membangkitkan semangat bekerja guna mencapaitujuan yang diinginkan merupakan hal yang sangat penting. Sebagaimana Allah SWT berfirman dalam Al-Qur'an Surat At-Taubah (9) ayat 105 sebagai berikut:

Artinya: "dan Katakanlah: Bekerjalah kamu, Maka Allah dan Rasul-Nya serta orang-orang mukmin akan melihat pekerjaanmu itu, dan kamu akan dikembalikan kepada (Allah) yang mengetahui akan yang ghaib dan yang nyata, lalu diberitakanNya kepada kamu apa yang telah kamu kerjakan" (Lembaga Percetakan Al Qur'an Kementerian Agama Republik Indonesia, 2010:273).

Pelaksanaan juga memiliki pengertian sebagai sebuah usaha menggerakkan anggota-anggota kelompok sedemikian rupa, sehingga mereka memiliki keinginan untuk mencapai tujuan yang telah ditetapkan bersaman melalui berbagai usaha. Sementara itu, pendapat lain mengenai fungsi pelaksanaan adalah menggambarkan bagaimana langkah-langkah yang ditempuh oleh seorang manajer dalam mempengaruhi para bawahannya untuk melaksanakan tugas yang telah diberikan dengan menciptakan suasana yang menyenangkan untuk bekerjasama .

Fungsi pelaksanaan dalam bidang pendidikan merupakan upaya memberikan arahan dan bimbingan serta dorongan kepada seluruh personal yang di 
madrasah sehingga mampu menjalankan tugasnya dengan baik. Fungsi pelaksanaan dalam manajemen terdapat beberapa istilah yang memiliki pengertian yang sama yaitu:

1) Motivating yaitu usaha untuk memberikan dorongan kepada seseorang untuk melakukan pekerjaan.

2) Directing yaitu memberikan tugas kepada orang lain untuk melakukan pekerjaan.

3) Staffing yaitu menempatkan seseorang pada suatu pekerjaan yang dijadikan sebagai tanggungjawabnya.

4) Leading yaitu memberikan bimbingan dan arahan kepada seseorang agar orang tersebut mau melakukan pekerjaan tertentu.

Berdasarkan pengertian di atas dapat disimpulkan bahwa fungsi pelaksanaan memiliki makna sebagai upaya yang dilakukan oleh seorang manajer untuk mempengaruhi semua anggota organisasi agar memiliki keinginan dan dorongan untuk melakukan usaha melalui pendayagunaan fasilitas yang tersedia dengan cara bekerja sama untuk mencapai tujuan sesuai dengan rencaca yang telah ditetapkan.

c. Fungsi Evaluasi

Evaluasi adalah adanya sebuah monitoring, pemeriksaan, pengukuran terhadap pelaksanaan dan hasil pelaksanaan termasuk audit mutu internal. Dengan demikian untuk melaksanakan fungsi evaluasi memerlukan sebuah pengawasan. Pengawasan adalah penemuan dan penetapan cara yang dilakukan oleh manajer untuk menjamin bahwa dalam pelaksanaan sebuah rencana sudah dilaksanakan sesuai dengan rencana yang sebelumnya sudah ditetapkan. Pengawasan pada hakekatnya adalah suatu usaha untuk memberikan petunjuk bagi para pelaksana kegiatan dengan tujuan untuk mengatur agar segala tindakan yang dilakukan sesuai dengan rencara yang telah ditetapkan dan berjalan dengan baik.

Makna dari pengawasan yang telah dijelaskan di atas memiliki maksud yang sama tersirat di dalam Al-Qur'an Surat Al-Hasyr (59) ayat ke 18 sebagai berikut:

Artinya: "Hai orang-orang yang beriman, bertakwalah kepada Allah dan hendaklah Setiap diri memperhatikan apa yang telah diperbuatnya untuk hari esok (akhirat); dan bertakwalah kepada Allah, Sesungguhnya Allah Maha mengetahui apa yang kamu kerjakan" . 
Pengawasan dalam manajemen memiliki peranan yang penting terutama dalam memastikan setiap pekerjaan yang dilakukan dapat terlaksana sesuai dengan yang direncanakan. Disamping itu pengawasan juga memiliki peran dalam membantu manajer dalam mengawasi dan mewujudkan visi dan misi perusahaan dan tidak terkecuali telah menempatkan manajer sebagai pihak yang memiliki wewenang sentral di suatu organisasi. Pengawasan memiliki manfaat yang positif yaitu mampu membangun hubungan yang baik antara pemimpin dan bawahan. Pengawasan dalam pendidikan bersifat kompleks yang mencakup pengawasan material dan pengawasan spiritual yaitu pengawasan tidak hanya dilakukan oleh seorang manajer tetapi langsung diawasi oleh Allah swt sehingga baik manajer maupun bawahan perlu adanya kesadaran untuk melakukan pekerjaan sebaikbaiknya.

Manajer dalam melakukan pengawasan harus memahami langkah-langkah yang harus dilakukan dalam melakukan pengawasan. Langakah - langkah tersebut antara lain adalah:

1) Menentukan sasaran dan tujuan dilakukannya pengawasan serta memahami lingkup pengawasan.

2) Mengidentifikasi komitmen pimpinan organisasi sebagai landasan utama melakukan pengawasan.

3) Menunjuk penanggung jawab pengawasan dan batasan wewenang untuk mengambil tindakan.

4) Menyusun perencanaan pengawasan secara utuh dan menyeluruh.

5) Menentukan kriterian dan batasan kegiatan yang harus diawasi.

6) Membuat dokumentasi seluruh rencana, prosedur, dan instruksi kerja pengawasan serta temuan-temuan dalam pengawasan.

7) Melaporkan hasil temuan kepada pimpinan yang bertanggungjawab terhadap kegiatan yang telah dilakukan pengawasan untuk memperoleh perhatian.

8) Mengambil tindakan koreksi atau pencegahan atas ketidakefisienan yang didentifikasi sewaktu pelaksanaan pengawasan.

9) Memberikan penilaian atas tindakan koreksi yang pernah dilakukan.

10) Memberikan penilaian atas tindakan pencegahan yang pernah dilaksanakan.

11) Memberikan penilaian keefektifan sistem yang berlaku dan identifikasi kemungkinan penyempurnaannya. 


\section{d. Fungsi tindak lanjut}

Tindak lanjut artinya melakukan evaluasi total terhadap hasil sasaran dan proses kemudian melakukan beberapa perbaikan jika ternyata apa yang telah kita kerjakan masih memiliki kekurangan. Oleh karena itu perlu segera melakukan perbaikan temuan kekurangan tersebut. Proses tindak lanjut sangat penting yaitu sebelum kita melakukan perbaikan selanjutnya maka perlu adanya upaya menyusun rencana perbaikan dan menyusun laporan pelaksanaan program pendidikan.

Menindaklanjuti hasil temuan untuk membuat perbaikan yang diperlukan berarti juga meninjau seluruh langkah dan memodifikasi proses untuk memperbaikinya sebelum implementasi berikutnya. Menindaklanjuti hasil berarti melakukan standarisasi perubahan, seperti mempertimbangkan area mana saja yang mungkin diterapkan, merevisi proses yang sudah diperbaiki, melakukan modifikasi standar, prosedur dan kebijakan yang ada, mengkomunikasikan kepada seluruh staf, pelanggan dan suplier atas perubahan yang dilakukan apabila diperlukan, mengembangkan rencana yang jelas, dan mendokumentasikan proyek. Selain itu, perlu juga memonitor perubahan dengan melakukan pengukuran dan pengendalian proses.

Melakukan tindakan perbaikan atas perbedaan yang signifikan antara hasil dilapangan dan yang direncanakan. Menganalisis perbedaan untuk menentukan akar permasalahannya. Menentukan langkah untuk menerapkan perubahan yang akan mencakup perbaikan proses atau produk. Apabila pada tahap tindak lanjut tidak membutuhkan upaya memperbaiki, ruang lingkup siklus PDCA dapat diterapkan untuk menyempurnakan perencanaan dan meningkatkan dengan lebih rinci pada pengulangan dari siklus berikutnya.

Berdasarkan penjelasan di atas tentang fungsi- fungsi manajemen menurut W. Edwards Deming yang meliputi perencanaan (planning), pelaksanaan (do), evaluasi (check), tindak lanjut (act), maka dapat digambarkan sebagai berikut:

Gambar II.1

Proses Lingkaran Deming

(Sumber : Zulkarnain Dali, Manajemen Mutu Madrasah, 2017, hal. 116) 
Terlihat jelas pada gambar di atas bagaimana sebuah mutu harus dipertahankan. Gambar di atas menunjukkan proses yang selalu berputar dari mulai perencanaan, pelaksanaan, pengawasan dan tindak lanjut saling berkesinambungan. Setelah melalui perencanaan yang matang, kemudian menjalankan proses pelaksanaan dan pengawasan. Kemudian dilakukan tindak lanjut dari hasil pengawasan yang nantinya hasil dari tindak lanjut akan menentukan perencanaan kegiatan yang akan datang.

\section{Manajemen Mutu}

Penafsiran yang timbul dari pengertian mutu yang selama ini diketahui oleh masyarakat bahwa mutu adalah sesuatu yang unggul, berkelas atau bernilai tinggi dan mahal harganya sehingga muncul kebiasaan untuk menilai mutu dengan membandingkan produk yang satu dengan yang lainnya (Zulkarnain Dali, 2017:81). Pemahaman tentang mutu seperti di atas tidak sepenuhnya benar, mutu dapat didefinisikan sebagai sesuatu yang bermutu harus mencakup berbagai macam produk, jasa, manusia, proses, dan lingkungan yang mampu memuaskan keinginan dan kebutuhan pelanggan .

Mutu mempunyai makna tingkat keunggulan suatu produk baik berupa barang ataupun jasa. Dalam konteks pendidikan, pengertian mutu mengacu pada proses pendidikan dan hasil pendidikan yaitu pendidikan yang bermutu banyak melibatkan berbagai aspek, seperti input, metodologi, dukungan administrasi dan sarana prasarana dan sumber daya lainya serta penciptaan suasana yang kondusif. Selain itu, mutu dalam konteks pendidikan juga mengacu pada proses pendidikan dan hasil pendidikan. Proses pendidikan yang bermutu melibatkan bahan ajar yang digunakan, metodologi pembelajaran yang bervariasi, dukungan administrasi, sarana prasarana yang memadai, dan berbagai sumber yang menciptakan suasana kondusif. Hasil pendidikan dinyatakan bermutu mengacu pada prestasi yang dicapai oleh satuan pendidikan setiap kurun waktu tertentu berupa hasil tes kemampuan akademik dan dapat pula dari bidang lain seperti olah raga, seni, atau keterampilan lainnya. Kedua unsur ini saling berkaitan sehingga tanggung jawab bukan hanya proses pendidikan saja tetapi hasil pendidikan yang diperoleh juga dijadikan sebagai tanggung jawab guna menjaga mutu dari satuan pendidikan tersebut .

Mutu pendidikan adalah derajat keunggulan dalam pengelolaan pendidikan secara efektif dan efisien untuk melahirkan keunggulan peserta didik dalam 
melaksanakan pendidikan dan menyelesaikan program pembeajaran tertentu. Mutu pendidikan bukanlah upaya yang sederhana melainkan sesuatu yang dinamis yang dinamis, dimana pendidikan akan terus berubah seiring perkembangan zaman. Maka dari itu perlu adanya upaya perbaikan secara terus-menerus demi tercapainya kebutuhan dan tuntunan kehidupan masyarakat.

Berdasarkan keterangan di atas dapat diketahui bahwa antara madrasah, pemerintah dan masyarakat harus ada keinginan yang sama untuk meningkatkan mutu pendidikan melalui pengelolaan sumber daya yang ada. Madrasah harus mampu menterjemahkan makna yang terkandung dalam kebijakan-kebijakan pendidikan yang dikeluarkan pemerintah serta harus memahami kelebihan dan kekurangan kondisi yang ada di lingkungan madrasah tersebut.

Menurut Arbangi, dkk delapan prinsip-prinsip manajemen mutu yang dapat digunakan sebagai kerangka dasar sebagai usaha seorang manajer dalam upaya meningkatkan mutu sebuar organisasi. Delapan prinsip tersebut adalah sebagai berikut:

a. Fokus pada pelanggan (Customer Focus)

Organisasi bergantung pada pelanggan mereka, karena itu manajemen organisasi harus memahami kebutuhan pelanggan sekarang dan yang akan datang. Organisasi harus memenuhi kebutuhan pelanggan dan giat berusaha melebihi ekspektasi pelanggan.

b. Kepemimpinan (Leadership)

Pemimpin organisasi harus menetapkan kesatuan tujuan dan arah dari organisasi. Mereka harus menciptakan dan memelihara lingkungan internal agar orang- orang dapat menjadi terlibat secara penuh dalam pencapaian tujuan- tujuan organisasi.

c. Keterlibatan Anggota (Involvement of people)

Anggota pada semua tingkatan dalam sebuah organisasi merupakan faktor yang sangat penting dari suatu organisasi itu sendiri. Sumbangsih dalamk keterlibatan mereka secara penuh akan menjadikan kemampuan mereka memungkinkan digunakan untuk manfaat kepentingan organisasi.

\section{d. Pendekatan proses (Process Orientation)}

Suatu hasil yang diinginkan akan tercapai secara efisien, apabila aktivitas dan sumber- sumber daya yang berkaitan dikelola sebagai suatu proses. Suatu proses dapat didefinisikan sebagai integrasi sekuensial dari 
orang, material, metode, mesin dan peralatan, dalam suatu lingkungan guna menghasilkan nilai tambah output bagi pelanggan.

e. Pendekatan sistem terhadap manajemen (System Approach to Management)

Pengidentifikasian, pemahaman dan pengelolaan, dari proses-proses yang saling berkaitan sebagai suatu sistem, akan memberikan kontribusi pada efektifitas dan efisiensi organisasi dalam mencapai tujuan-tujuannya.

f. Perbaikan berkesinambungan (Continual Improvement)

Perbaikan berkesinambungan atas kinerja organisasi secara keseluruhan harus menjadi tujuan tetap dari organisasi. Proses perbaikan berkesinambungan didefinisikan sebagai suatu proses yang berfokus pada upaya terus- menerus meningkatkan efektifitas dan atau efisiensi organisasi untuk memenuhi kebijakan dan tujuan dari organisasi itu. Upaya perbaikan kualitas secara berkesinambungan dalam lembaga pendidikan harus menggunakan pendekatan atas fungsi inti lembaga pendidikan yaitu pendekatan akreditasi, pendekatan outcome assessment, dan pendekatan sister terbuka.

g. Pendekatan faktual dalam pembuatan keputusan (Factual Approach to Decision Making)

Keputusan yang efektif adalah keputusan yang berdasarkan pada analisis data dan informasi untuk menghilangkan informasi yang bias melalui kebiasaan membangun fakta dan analisis sebelum mengambil keputusan, sehingga masalah-masalah kualitas dapat terselesaikan secara efektif dan efisien.

h. Hubungan saling menguntungkan dengan pemasok (Mutually Beneficial Supplier Relationship)

Suatu organisasi dan pemasok atau masyarakat adalah saling ketergantungan satu dengan lainnya, dan suatu hubungan yang saling menguntungkan akan meningkatkan kemampuan bersama dalam menciptakan nilai tambah bagi keduanya. Hubungan yang kuat antara organisasi dengan pemasok dapat menjamin terjadinya perbaikan mutu secara berkesinambungan dalam menghasilkan barang dan jasa.

Berdasarkan pemaparan di atas dalam upaya untuk pengelolaan sebuah manajemen mutu melalui prinsip-prinsip manajemen mutu, perlu adanya sebuah strategi yang dapat diimplementasikan sebgaia upaya pengelolaan mutu. Dalam dunia pendidikan, strategi pengelolaan mutu dianggap sangat penting sebagai alat bantu dalam pengelolaan mutu. Zulkarnain Dali menyatakan beberapa strategi yang dapat 
diimplementasikan pada madrasah dalam upaya pengelolaan mutu diantaranya adalah sebagai berikut:

a. Fokus pada peserta didik

Fokus pada peserta didik sebagai strategi peningkatan mutu madrasah dirasa sangat penting dalam rangka memberikan pelayanan agar mereka dapat mengikuti proses pendidikan sebaik-baiknya. Penyusunan kurikulum, perangkat pembelajaran, sumber daya pendidik serta sarana dan prasarana yang ada harus diperhatikan dengan sungguh-sungguh. Hal ini dilakukan dengan tujuan agar hasil pendidikan yang diperoleh maksimal.

b. Obsesi terhadap kualitas

Proses pembelajaran yang dilakukan oleh madrasah harus disesuaikan dengan standar mutu yang telah ditetapkan oleh madrasah itu sendiri. Dengan kata lain bahwa proses pembelajaran yang dilakukan harus terobsesi untuk mencapai atau melampaui standar mutu yang telah ditetapkan. Oleh karena itu, perlu adanya motivasi yang tinggi dalam pencapaian standar mutu secara maksimal.

c. Pendekatan ilmiah

Pendekatan ilmiah sangat diperlukan sebagai kendali dari mutu sebuah madrasah. Usaha yang harus dilakukan dengan mendesain proses pendidikan dan pembelajaran. Pendekatan ilmiah dapat dilakukan dengan cara memunculkan ciri khas madrasah itu sendiri, meningkatkan prestasi peserta didik atau dengan cara melakukan perbaikan proses pembelajaran.

d. Komitmen jangka panjang

Komitmen jangka panjang dilakukan dengan cara menciptakan budaya yang kondusif dari madrasah. Apabila budaya madrasah sudah kondusif maka komitmen madrasah untuk melakukan kendali mutu dapat direalisasikan. Komitmen jangka panjang dirasa penting guna menjaga atau mengevaluasi pelaksanaan implementasi kendali mutu.

e. Standar mutu peserta didik

Peserta didik sebagai subjek pendidikan harus dilibatkan dalam menentukan arah pembelajaran pada suatu madrasah. Dengan melibatkan peserta didik diharapkan mereka memiliki tanggung jawan untuk mencapai tujuan yang telah ditetapkan bersama. Akan tetapi perlu adanya pembatasan-pembatasan terhadap peserta didik agar tidak bersimpangan dengan tujuan madrasah. 
Prinsip mutu dapat diterjemahkan sebagai sejumlah asumsi yang dinilai dan diyakini bahwa prinsip mutu memiliki kekuatan untuk mewujudkan mutu. Dengan demikian sebuah organisasi apabila mengehendaki memiliki mutu yang bagus harus terlebih dahulu memahami secara mendalam mengenai prinsip-prinsip mutu agar memperoleh kemudahan dalam upaya mewujudkan mutu tersebut. Menurut W. Edwards Deming, prinsip mutu yang harus dilakukan oleh sebuah organisasi atau perusahaan jika menginginkan tercapainya sebuah mutu yang dikehendaki oleh organisasi atau perusahaan tersebut ada empat belas prinsip. Prinsip-prinsip yang dimaksud yaitu:

a. Menciptakan konsistensi tujuan untuk pengembangan produk dan jasa dengan adanya tujuan suasana bisnis yang kompetitif.

b. Melakukan adopsi filosofi baru.

c. Menghentikan ketergantungan pada asanya indpeksi dan digantikan dengan upaya pencapaian mutu.

d. Menghentika anggapan bahwa penghargaan dalam bisnis adalah terletak pada harga.

e. Peningkatan sistim prosukdi dan layanan secara terus menerus guna peningkatan mutu dan prosuktifitas.

f. Melakukan pelatihan dalam pekerjaan.

g. Kepemimpinan lembaga.

h. Menghilangkan rasa takut.

i. Hilangkan penghalang antar departemen atau biro.

j. Mengurangi slogan peringatan-peringatan dan target kemudian mengganti dengan pemantapan metode-metode yang dapat meningkatkan mutu kerja.

k. Kurangi standar kerja yang menentukan kuota berdasarkan jumlah.

1. Hilangkan penghambat yang dapat merampas hak asasi manusia untuk merasa bangga terhadap kercakapan kerjanya.

m. Lembagakan suatu program pendidikan dan peningkatan diri yang penuh semangat.

n. Setiap orang dalam perusahaan bekerja sama dalam mendukung proses transformasi. ${ }^{7}$

\footnotetext{
${ }^{7}$ Syafaruddin, Efektifitas Kebijakan Pendidikan Konsep, Strategi,Dan Aplikasi Kebijakan Menuju Organisasi Sekolah Efektif (Jakarta: Roneka Cipta, 2008).
} 
Penilaian mutu pendidikan dilakukan dengan mengukursecara universal yang meliputi input, proses, output maupun outcome. Penilaian mutu ini dilakukan harus berdasarkan beberapa karakteristik dari mutu itu sendiri. Menurut Arbangi (2016:90) mengemukakan bahwa karakteristik mutu adalah sebagai berikut:

a. Kinerja (performance) bekaitan dengan aspek fungsional dari produk dan merupakan karakteristik utama yang dipertimbangkan pelanggan ketika ingin membeli suatu produk adalah melihat dari karakteristik produk itu sendiri.

b. Keistmewaan (features) merupakan aspek kedua dari kinerja yang menambah fungsi dasar yang berkaitan dengan pilihan-pilihan dan pengembangannya melalui ciri-ciri atau keistimewaan tambahan.

c. Kehandalan (reliability) berkaitan dengan kemungkinan suatu produk berfungsi secara berhasil dalam periode waktu tertentu di bawah kondisi tertentu yang merefleksikan kemungkinan tingkat keberhasilan suatu produk yag dihasilkan

d. Standar tertentu (conformance) berkaitan dengan tingkat keseuaian produk terhadap spesifikasi yang telah ditetapkan sebelumnya berdasarkan keinginan pelanggan.

e. Daya tahan (durability) berkaitan dengan jangka waktu seberapa lama produk yang dihasilkan dapat terus digunakan dan dapat bertahan lama untuk tetap dimanfaatkan.

f. Pelayanan (serviceability) berkaitan dengan kecepatan, kesopanan, kompetensi dan kemudahan serta penanganan keluhan yang memuaskan.

g. Estetika (aesthetics) berkaitan dengan keindahan yang bersifat subjektif sehingga berkaitan dengan pertimbangan pribadi dan refleksi dari pilihan individu.

h. Kualitas yang dipersepsikan (perceived quality) berkaitan dengan reputasi dari produk yang dihasilkan.

Berdasarkan keterangan di atas, menurut Ara Hidayat. dkk, kepala madrasah dalam upayanya untuk meningkatkan mutu pendidikan di madrasah setidaknya harus memperhatikan tiga aspek yang menentukan tercapainya tujuan madrasah yaitu:

a. Pengembangan kurikulum yang relevan dengan kebutuhan madrasah

b. Pembinaan profesional guru dan tenaga kependidikan.

c. Pengadaan dan pendayagunaan sarana dan prasarana madrasah.

Selain itu, keberhasilan desentralisasi pendidikan pada saat ini dalam upaya untuk mengetahui sejauh mana usaha peningkatan mutu madrasah sedikitnya dapat 
dilihat dari tiga dimensi yaitu efektivitas, efisiensi dan produktifitas (Mulyasa, 2017:92). Lebih terperinci dari ketiga dimensi tersebut adalah sebagai berikut:

a. Efetivitas

Efektivitas adalah terciptanya kesesuaian dan kesamaan pemikiran antara orang yang melaksanakan tugas dengan sasaran atau tujuan yang telah dituju. Dengan demikian efektivitas berkaitan dengan tercapainya tugas pokok, tercapainya tujuan, ketepatan waktu, dan adanya partisipati aktif dari anggota.

b. Efisiensi

Efisieni lebih ditekankan pada perbandingan antara input dengan output yaitu suatu kegiatan dikatakan efisien apabila tujuan yang ingin dicapai dapat dilaksanakan secara optimal dengan penggunaan sumber daya yang minimal.

c. Produktivitas

Produktivitas dalam dunia pendidikan berkaitan dengan keseluruhan proses penataan, pemnafaatan dan penggunaan sumber daya yang ada dengan maksud untuk mencapai tujuan pendidikan secara efektif dan efisien.

\section{Upaya Meningkatkan Kemandirian}

Kemandirian memiliki makna memberdayakan madrasah melalui pemberian wewenang (otonomi) kepada madrasah dengan melakukan pemberian fleksibelitas yang lebih besar untuk mengelola sumber daya yang ada dalam madrasah tersebut serta mendorong partisipasi aktif dari warga masyarakat untuk meningkatkan mutu pendidikan. Adapun beberapa ciri-ciri kemandirian yang perlu diketahui sebagai berikut:

a. Kepala madarsah harus mampu berfikir dan berbuat secara aktif, kreatif, kompoten dan tidak bergantung pada orang lain dalam melakukan sesuatu.

b. Kepala madarsah harus mempunyai kecendrungan memecahkan masalah dan berusaha mencari cara untuk menyelesaikan masalah yang dihadapi.

c. Kepala madarsah harus berani mengambil resiko dengan mempertimbangkan baik buruknya dalam menetukan keputusan.

d. Kepala madarsah harus percaya terhadap penilaian sendiri

Selain itu dalam upaya peningkatan kemandirian madrasah harus memperhatikan tujuan dari pembangunan pendidikan nasional yang meliputi tiga pilar pengembangan pendidikan antara lain: (1) perluasan dan pemerataan akses 
memperoleh pendidikan, (2) peningkatan mutu dan relevansi pendidikan dan daya saing, (3) peningkatan efisiensi dan efektivitas pengelolaan pendidikan.

Berdasarkan hal tersebut di atas upaya yang dilakukan dalam meningkatkan kemandirian madarsah dengan melakukan manajemen mutu yang baik dengan berdasarkan pada delapan standar nasional pendidikan yang telah diatur dalam Peraturan Pemerintah Nomor 32 tahun 2013 sebagai berikut:

a. Standar Isi adalah kriteria mengenai ruang lingkup materi dan tingkat kompetensi untuk mencapai kompetensi lulusan pada jenjang dan jenis pendidikan tertentu.

b. Standar Proses adalah kriteria mengenai pelaksanaan pembelajaran pada satu satuan pendidikan untuk mencapai Standar Kompetensi Lulusan.

c. Standar Kompetensi Lulusan adalah kriteria mengenai kualifikasi kemampuan lulusan yang mencakup sikap, pengetahuan, dan keterampilan.

d. Standar Pendidik dan Tenaga Kependidikan adalah criteria mengenai pendidikan prajabatan dan kelayakan maupun mental, serta pendidikan dalam jabatan.

e. Standar Sarana dan Prasarana adalah kriteria mengenai ruang belajar, tempat berolahraga, tempat beribadah, perpustakaan, laboratorium, bengkel kerja, tempat bermain, tempat berkreasi dan berekreasi serta sumber belajar lain, yang diperlukan untuk menunjang proses pembelajaran, termasuk penggunaan teknologi informasi dan komunikasi.

f. Standar Pengelolaan adalah kriteria mengenai perencanaan, pelaksanaan, dan pengawasan kegiatan pendidikan pada tingkat satuan pendidikan, kabupaten kota, provinsi, atau nasional agar tercapai efisiensi dan efektivitas penyelenggaraan pendidikan.

g. Standar Pembiayaan adalah criteria mengenai komponen dan besarnya biaya operasional satuan pendidikan yang berlaku selama satu tahun.

h. Standar Penilaian Pendidikan adalah kriteria mengenai mekanisme, prosedur, dan instrument penilaian hasil belajar Peserta Didik.

\section{KESIMPULAN}


Berdasarkan pada latar belakang masalah, rumusan masalah, dan pemaparan hasil penelitian tentang manajemen mutu pendidikan dalam upaya meningkatkan kemandirian madrasah dapat disimpulkan sebagai berikut:

1. Perencanaan manajemen mutu pendidikan di MI Ma`arif Adikarso Kecamatan Kebumen.

Perencanaan manajemen mutu pendidikan standar isi dilakukan dengan membentuk tim penyusun kurikulum. Perencanaan manajemen mutu standar proses meliputi penyusunan perangkat pembelajaran. Perencanaan manajemen standar kompetensi lulusan dilakukan dengan rapat membahas kriteria standar kompetensi lulusan. Perencanaan manajemen mutu standar pendidik dan tenaga kependidikan adalah dengan melakukan seleksi calon pendidik yang melamar dengan ketentuan utama pendidikan minimal S1. Perencanaan manajemen mutu standar sarana dan prasarana dilakukan dengan rapat membahas keadaan sarana dan prasarana madrasah. Perencanaan manajemen mutu standar pengelolaan dilakukan dengan rapat penyusunan visi, misi, dan tujuan madrasah serta rencana kerja madrasah. Perencanaan manajemen mutu standar pembiayaan dilakukan dengan rapat penyusunan rencana kerja anggaran madrasah (RKAM). Perencanaan manajemen mutu standar penilaian adalah dengan rapat penetapan KKM madrasah, menyusun pedoman penilaian hasil belajar dan penilaian akhir, menyusun pedoman kriteria kenaikan kelas dan kelulusan peserta didik.

Berdasarkan kesimpulan dari perencanaan masing-masing standar nasional pendidikan, dapat diketahui bahwa dalam melakukan perencanaan manajemen mutu pendidikan di MI Ma`arif Adikarso Kecamatan Kebumen sudah dilakukan dengan baik. Dalam melaksanakan perencanaan manajemen mutu pendidikan diawali 
dengan rapat bersama untuk menentukan tujuan yang akan dicapai melalui berbagai program.

2. Pelaksanaan manajemen mutu pendidikan di MI Ma`arif Adikarso Kecamatan Kebumen.

Pelaksanaan manajemen mutu standar isi adalah dengan menyusun kurikulum MI Ma`arif Adikarso Kecamatan Kebumen. Pelaksanaan manajemen mutu standar proses dilakukan dengan melaksanakan proses belajar mengajar dengan berpedoman pada RPP. Pelaksanaan manajemen mutu standar komptenesi lulusan dilakukkan dengan menyusun program kerja madrasah sebagai dasar pelaksanaan kegiatan madrasah. Pelaksanaan manajemen mutu pendidik dan tenaga kependidikan dilakukan dengan beberapa cara yaitu mengikutsertakan pendidik dalam pelatihan dan workshop, kegiatan kelompok kerja guru madrasah ibtidaiyah, serta ajang lomba karya ilmiah. Pelaksanaan manajemen mutu standar sarana dan prasarana dilakukan dengan pengecekan kondisi sarana dan prasarana. Pelaksanaan manajemen mutu standar pengelolaan dilakukan dengan berlandaskan pada rencana kerja madrasah. Pelaksanaan manajemen mutu standar pembiayaan dilakukan berdasarkan pada RKAM. Pelaksanaan manajemen mutu standar penilaian dilakukan dengan menyusun kisi-kisi penilaian, menyusun instrumen penilaian dan pedoman penilaian, melakukan penilaian dan menganalisis hasil penilaian, serta menyerahkan laporan hasil belajar kepada orang tua wali peserta didik.

Berdasarkan kesimpulan dari pelaksanaan masing-masing standar nasional pendidikan, dapat diketahui bahwa dalam pelaksanaan manajemen mutu pendidikan di MI Ma`arif Adikarso Kecamatan Kebumen sudah dilakukan dengan baik. Dalam pelaksanaan manajemen mutu pendidikan, kepala madrasah mampu menggerakan pendidik untuk menjalankan pogram sesuai dengan rencana yang telah dibuat. 
3. Evaluasi manajemen mutu pendidikan di MI Ma`arif Adikarso Kecamatan Kebumen.

Evaluasi manajemen mutu standar isi dilakukan melalui forum rapat kepala madrasah dan pendidik dengan melaporkan hasil kegiatan pembelajaran yang telah dilaksanakan. Evaluasi manajmen mutu standar proses dilakukan dengan melaksanakan kegiatan supervisi oleh kepala madrasah dan pengawas madrasah. Evaluasi manajemen mutu standar kompetensi lulusan dilakukan dengan rapat untuk membahas pelaksanaan program madrasah selama satu tahun pelajaran. Evaluasi manajemen mutu standar pendidik dan tenaga kependidikan dilakukan dengan melaksanakan supervisi oleh kepala madrasah dengan memberikan penilaian dan masukan terhadap kinerja pendidik dalam melakukan pembelajaran. Evaluasi manajemen mutu sarana dan prasarana dilakukan dengan mengadakan rapat bersama membahas perbaikan dan pengadaan sarana dan prasarana madrasah yang dibutuhkan. Evaluasi manajemen mutu standar pengelolaan dilakukan melalui monitoring oleh kepala madrasah untuk memastikan bahwa pengelolaan manajemen berjalan dengan lancar. Evaluasi manajemen mutu standar pembiayaan dilakukan dengan melakukan pemeriksaan terhadap penggunaan keuangan madrasah. Evaluasi manajemen standar penilaian dilakukan dengan rapat untuk membahas kenaikan kelas dan rapat kelulusan peserta didik.

Berdasarkan kesimpulan dari kegiatan evaluasi masing-masing standar nasional pendidikan, dapat diketahui bahwa dalam kegiatan evaluasi manajemen mutu pendidikan di MI Ma`arif Adikarso Kecamatan Kebumen sudah dilakukan dengan baik. Kepala madarsah dalam menjamin terlaksananya manajemen mutu pendidikan di MI Ma`arif Adikarso Kecamatan Kebumen dilakukan supervisi dan rapat evaluasi terhadapt pelaksanaan manajemen mutu untuk mencari kekurangan dan kelemahan dari pelaksanaan manajemen mutu pendidikan. 
4. Tindak lanjut manajmen mutu pendidikan di MI Ma`arif Adikarso Kecamatan Kebumen.

Tindak lanjut manajemen mutu standar isi dilakukan dengan rapat bersama untuk mencari solusi perbaikan dari temuan kekurangan selama pelaksanaan manajemen mutu standar isi. Tindak lanjut manajemen mutu standar proses dilakukan dengan memberikan penguatan dan penghargaan kepada pendidik yang menunjukkan kinerja yang memenuhi standar dan pemberian kesempatan kepada pendidik untuk mengikuti program pengembangan keprofesionalan berkelanjutan. Tindak lanjut manajemen standar kompetensi lulusan dilakukan dengan menyusun kembali program kerja madrasah untuk tahun pelajaran berikutnya dengan disesuaikan pada tiga dimensi yaitu sikap, pengetahuan, dan keterampilan. Tindak lanjut manajemen standar pendidik dan tenaga kependidian dilakukan melalui diskusi bersama untuk mencari pemecahan masalah dari hasil supervisi. Tindak lanjut manajemen mutu standar sarana dan prasarana dilakukan dengan mengadakan rapat bersama membahas penyusunan rencana kerja anggaran madrasah dengan materi pengadaan dan perawatan sarana dan prasarana. Tindak lanjut manajemen mutu standar pengelolaan dilakukan dengan supervisi secara terus-menerus agar pendidik memahami tugasnya dan mampu melaksanakan tugas dengan sebaikbaiknya. Tindak lanjut manajemen mutu standar pembiayaan dilakukan dengan mengadakan rapat bersama komite, kepala madrasah dan pendidik untuk membahas hasil evaluasi penggunaan keuangan madrasah yang digunakan sebagai acuan perumusan rencana kegiatan anggaran madrasah selanjutnya. Tindak lanjut manajemen mutu standar penilaian dilakukan dengan mengadakan rapat untuk merumuskan kembali kriteria ketuntasan minimal dan standar kompetensi lulusan 
berdasarkan pada hasil evaluasi dengan melihat pada karakteristik dan kemampuan dari masing-masing peserta didik.

B. Berdasarkan kesimpulan dari tindak lanjut masing-masing standar nasional pendidikan, dapat diketahui bahwa dalam kegiatan tindak lanjut manajemen mutu pendidikan di MI Ma`arif Adikarso Kecamatan Kebumen sudah dilakukan dengan baik. Dalam pelaksanaan tindak lanjut, kepala madrasah menggunakan dasar tahapan evaluasi untuk menentukan langkah tindak lanjut yang akan dilakukan

\section{DAFTAR PUSTAKA}

Bafadal, Ibrahim. (2003). Manajemen Peningkatan Mutu Sekolah Dasar, Jakarta: Bumi Aksara.

Direktorat Jenderal Pendidikan Tinggi Menenterian Pendidikan dan Kebudayaan, Buku Panduan Program Bantuan Pengembangan Sistem Penjaminan Mutu Internal untuk Pembinaan Program Studi, 2021

Fathinahaya N, dkk. "Manajemen Kepemimpinan Pendidikan Islam pada Sekolah Internasional di Indonesia”, Jurnal Pandawa, Volume 4, Nomor 1, Januari 2022

Machali, Imam dan Ara Hidayat. (2016). Manajemen Teori dan Praktik Pengolahan Sekolah/Madrasah di Indonesia. Jakarta: Kencana.

Suhartono, Fatimah, S., Widyastuti, S. (2018). Analisis Keterlaksanaan dan Pengaruh Kemitraan Sekolah, Keluarga, dan Masyarakat terhadap Kualitas Pendidikan di SD Negeri 02 Karangsari Kebumen. Dwija Cendekia: Jurnal Riset Pedagogik. Vol 2 (1): 61-71.

Syukur, Fattah. (2011). Manajemen Pendidikan Berbasis Madrasah. Semarang: Pustaka Rizki Putra.

Triwiyanto, Teguh. (2015). Manajemen Kurikulum dan Pembelajaran. Jakarta: Bumi Akasara.

Usman, Husaini. (2012). Manajemen: Teori Praktik dan Riset Pendidikan. Jakarta: Bumi Aksara. 